\title{
Pengaruh minat belajar terhadap kemampuan komunikasi matematis siswa SMP kelas VII
}

\author{
Nur'aini Mar'atush Sholihat, Kiki Nia Sania Effendi, Khaerudin \\ Pendidikan Matematika, FKIP, Universitas Singaperbangsa Karawang, Jawa Barat, Indonesia \\ E-mail: 1610631050112@student.unsika.ac.id
}

\begin{abstract}
ABSTRAK
Tujuan dari penelitian ini adalah untuk mengetahui pengaruh minat belajar terhadap kemampuan komunikasi matematis siswa SMP kelas VII pada saat pandemi COVID 19. Sampel pada penelitian ini sebanyak 36 siswa kelas VII J di SMP Negeri 1 Karawang. Pengumpulan data dengan cara menyebarkan angket minat belajar dengan menggunakan bantuan google from dan tes kemampuan komunikasi matematis dengan menggunakan bantuan aplikasi whatsapp. Penelitian ini merupakan penelitian kuantitatif dengan metode penelitian correlational research. Teknik analisis data yang digunakan yaitu uji regresi linear sederhana. Hasil dari penelitian ini yaitu minat belajar matematika berada pada kategori cukup baik, dan nilai rata-rata tes kemampuan komunikasi matematis siswa masih berada di bawah nilai kriteria ketuntasan minimal (KKM). Persentase koefisien determinasi yang dihasilkan sebesar 2\%. Artinya $2 \%$ variansi kemampuan komunikasi matematis dapat dijelaskan oleh variasi dari minat belajar matematika siswa. Sedangkan 98\% lainnya dijelaskan oleh sebab-sebab diluar model regresi Akibat kecilnya koefisien determinasi, pengaruh minat terhadap kemampuan komunikasi matematis menjadi tidak signifikan. Diperoleh nilai signifikansi sebesar 0,420 lebih dari 0,05, maka $\mathrm{H}_{0}$ diterima. Artinya tidak terdapat pengaruh minat belajar terhadap kemampuan komunikasi matematis siswa SMP kelas VII saat pandemi COVID 19.
\end{abstract}

Kata Kunci: Minat; Belajar; Kemampuan Komunikasi Matematis.

\begin{abstract}
The purpose of this study was to determine the effect of interest in learning on the mathematical communication skills of grade VII junior high school students during the COVID 19 pandemic. The sample in this study was 36 students of class VII J at SMP Negeri 1 Karawang. Collecting data by distributing questionnaires of interest in learning using the help of google from and tests of mathematical communication skills using the help of the WhatsApp application. This research is a quantitative research with correlational research method. The data analysis technique used is simple linear regression test. The results of this study are that the interest in learning mathematics is in the fairly good category, and the average score of the students' mathematical communication skills test is still below the minimum completeness criteria (KKM). The resulting coefficient of determination percentage of $2 \%$. This means that $2 \%$ of the variance in mathematical communication skills can be explained by variations in students' interest in learning mathematics. Meanwhile, the other $98 \%$ are explained by causes outside the regression model. Due to the small coefficient of determination, the effect of interest on mathematical communication skills becomes insignificant. Obtained a significance value of 0.420 more than 0.05 , then $H_{-} 0$ is accepted. This means that there is no influence of interest in learning on the mathematical communication skills of seventh grade junior high school students during the COVID 19 pandemic.
\end{abstract}

Keywords: Interest; Lerning; Mathematical communication skills. 


\section{PENDAHULUAN}

Berdasarkan Peraturan Pemerintah Republik Indonesia Nomor 32 Tahun 2013 Tentang Perubahan Atas Peraturan Pemerintah Nomor 19 Tahun 2005 Tentang Standar Nasional Pendidikan pasal 77J ayat 1 yang menyatakan bahwa struktur kurikulum SMP/MTs/SMPLB atau bentuk lain sederajat salah satunya terdiri atas mata pelajaran matematika. Matematika identik dengan sifatnya yang abstrak, sehingga membuat siswa dari setiap tingkatan mengalami kesulitan dalam mempelajarinya. Menurut Martin (Sundayana, 2016) menyatakan bahwa objek matematika yang abstrak merupakan kesulitan tersendiri bagi setiap siswa yang mempelajarinya.Kesulitan yang dialami oleh siswa dapat mengakibatkan siswa tidak merasa senang saat mempelajari matematika. Perasaan senang merupakan salah satu tolak ukur atau indikator dari minat belajar. Menurut Tambunan (2016) minat merupakan salah satu faktor dalam diri seseorang yang dapat mempengaruhi tindakan yang dilakukan seseorang. Jika seorang memiliki minat maka ia akan berusaha dengan gigih dan serius serta tidak mudah putus asa dalam menghadapi tantangan.

Minat sangatlah diperlukan dalam proses pembelajaran, minat yang dapat mempengaruhi siswa disebut dengan minat belajar. Menurut Slameto(Rojabiyah dan Setiawan, 2019) minat belajar adalah kecenderungan seseorang yang tetap untuk mengenang dan memfokuskan pikirannya kepada beberapa kegiatan. Terdapat indikator minat belajar yang digunakan untuk menjadi tolak ukur tinggi atau rendahnya minat belajar siswa. Berikut indikator minat belajar indikator dari minat belajar menurut Bown(Hamidah dan Setiawan, 2019) yaitu: 1) Perasaan senang, 2) Ketertarikan, 3) Perhatian dan keterlibatan dalam belajar,4) rajin belajar dan rajin mengerjakan tugas, 5) tekun dan disiplin dalam belajar,6) memiliki jadwal belajar.Minat belajar siswa memiliki pengaruh yang besar terhadap proses pembelajaran siswa.

Materi yang dipelajari sesuai dengan minat siswa, maka rasa keinginan yang besar untuk memahami bahkan mendalami bahan pelajaran itu. Menurut Khairani (2017) minat besar pengaruhnya terhadap aktivitas belajar akan mendorong individu bersungguh-sungguh, senang mengikuti penyajian peajaran tertentu, dan dapat menyelesaikan kesulitankesulitan dalam belajar atau menyelesaikan soal-soal praktikum. Pada nyatanya minat belajar siswa pada pembelajaran matematik masih tergolong rendah sehingga dapat mempengaruhi kemampuan matematis siswa. Menurut Tambunan (2016) menyatakan bahwa tinggi rendahnya kemampuan matematis siswa bergantung kepada tinggi rendahnya minat belajar siswa.

Terdapat beberapa kemampuan matematis siswa yang telah dirumusakan oleh National CouncilofTeacherofMathematics(Rahmayani \& Effendi, 2019)yaitu salah satu dari kemampuan matematis siswa terdapat kemampuan komunikasi matematis siswa. Kemampuan komunikasi matematis merupakan kemampuan yang mendasar dari pembelajaran matematika. Menurut National CouncilofTeacherofMathematics(NCTM) (Ritonga, 2019) komunikasi merupakan bagian yang esensial dari matematika dan pendidikan matematika.Sejalan dengan hal tersebut menurut Permendikbud Nomor 21 Tahun 2016 Tentang Standar Isi Pendidikan Dasar dan Menengah memiliki kemampuan mengkomunikasikan gagasan matematika dengan jelas. Komunikasi matematis merupakan suatu kegiatan pertukaran informasi dari penyalur kepada penerima informasi baik secara lisan maupun tulisan. Menurut Auliana (Fatkhiyyah, dkk, 2019) bahwa kemampuan komunikasi matematika adalah kemampuan menerima gagasan/ide matematika dari orang lain secara teliti, kritis, dan evaluatif kemudian memahaminya untuk mempertajam pemahamannya terhadap matematika, dan juga sebagai kemampuan dalam menyampaikan gagasan/ teori/ ide matematika baik secara lisan maupun tuliasan.Terdapat beberapa 
indikator kemampuan komunikasi matematis menurut Soemarmo(Hendriana \& Suemarmo, 2019)1)Menyatakan benda-benda nyata, situasi dan peristiwa sehari-hari ke dalam bentuk model matematika (gambar, tabel, diagram, grafik, ekspresi aljabar); 2) Menjelaskan ide, dan model matematika (gambar, tabel, diagram, grafik, ekspresi aljabar) ke dalam bahasa biasa; 3) Menjelaskan dan membuat pertanyaan matematika yang dipelajari; 4) Mendengarkan, berdiskusi dan menulis tentang matematika; 5) Membaca dengan pemahaman suatu prestasi tertulis; 6) Membuat konjektur, menyusun argumen, merumuskan definisi dan generalisasi.

Kemampuan komunikasi matematis merupakan salah satu kemampuan terpenting dalam pembelajaran matematika. Menurut Asikin (Qonaah, Pujiastuti, \& Fatah, 2019) mengungkapkan bahwa peran penting komunikasi matematis dalam pembelajaran matematika antara lain untuk mengukur pemahaman matematis siswa. Namun,pada nyatanya kemampuan komunikasi matematis siswa masih berada pada kategori rendah khususnya pada materi trapesium, jajargenjang dan layang-layang. Berdasarkan kesimpulan hasil penelitian Sholihat \& Effendi (2019) menyatakan bahwa kemampuan komunikasi matematis siswa pada materi segiempat berada dikategori sangat rendah. Sejalan dengan hasil penelitian tersebut Wijayanto,dkk (2018) menyatakan bahawa kemamapuan komunikasi matematis siswa SMP pada materi Segitiga dan Segiempat masih termasuk kategori rendah. Pada dasarnya materi trapesium, jajargenjang dan layang-layang sering dijumpai dalam kehidupan sehari-hari, seperti contohnya menghitung luas lahan, menentukan tinggi maksimum siswa untuk melompati papan lompat kangkang dan lain sebagainya. Berdasarkan latar belakang diatas, terdapat tujuan dari penelitian ini yaitu untuk mengetahui pengaruh minat belajar terhadap kemampuan komunikasi matematis siswa SMP kelas VII saat pandemi COVID 19.

Penelitian ini dilaksanakan karena mengingat pada awal tahun 2020, proses pembelajaran di Indonesia yang harusnya dilaksanakan secara langsung atau tatap muka namun saat ini proses pembelajran dilaksanakan secara online. Banyak kendala yang dialami oleh siswa pada saat pembelajaran seperti masalah jaringan sehingga menyebabkan guru menerangkan tidak terlalu jelas, sehingga dapat menyebabkan siswa merasa bosan dan jenuh saat belajar. Dengan demikian, minat belajar siswa sebelum dan saat pandemi itu berbeda sehingga hal tersebut dapat mempengaruhi kemampuan matematis siswaMenurut Tuncay dan Uzunboly (Sukardi \& Rozi, 2019) pembelajaran ol-learning secara murni tidak memungkinkan terjadinya tatap muka didalam kelas sehingga keseluruhan kebutuhan pembelajaran tidak terakomodasi dengan baik, sehingga pembelajaran ol-learning tidak efektif untuk meningkatkan keomunikasi siswa.

\section{METODE PENELITIAN}

Metode penelitian yang digunakan yaitu correlational research jenis regresi. Menurut Arifin (2011) correlational research jenis regresi ini merujuk pada seberapa baik prediksi yang telah dibuat. Sebagaimana pendekatan koefisien korelasi baik -1 ataupun +1 , prediksi yang dibuat dikatakan baik. Correlational research digunakan untuk mencari tahu hubungan anatar variabel minat belajar terhadap variabel kemampuan komunikasi matematis.

Penelitian ini dilaksanakan pada tanggal 31 Maret 2020 sampai tanggal 08 April 2020. Di salah satu sekolah menengah pertama di Kabupaten Karawang. Dalam memilih sampel untuk penelitian ini dilakukan teknik sampling. Macam teknik sampling yang digunakan adalah probability sampling dengan jenis clusterrandom sampling. Azwar (Maula \& Kustanti, 2020) menjelaskan bahwa clusterrandom sampling adalah pengambilan anggota 
sampel yang dilakukan pada kelompok, bukan terhadap subjek secara individual. Maka pengambilan sampelnya berdasarkan daerah populasi yang telah di tetapkan.. Dari hasil pemilihan sampel dengan clusterrandom sampling maka diperoleh sampel penelitian pada penelitian ini yaitu siswa kelas VII J.

Teknik pengumpulan data pada penelitian ini yaitu dengan cara pemberian instrumen soal kemampuan komunikasi matematis kepada siswa kelas VII J yang dilakukan secara online. Sedangkan untuk data minat belajar diperoleh dari pemberian angket secara online dengan menggunakan bantuan aplikasi googlefromdan kegiatan wawancara mengenai minat dan kemampuan komunikasi matematis siswa dengan bantuan aplikasi zoom. Data hasil tes dan angket yang telah terkumpul diolah dengan menggunakan statistik yang sesuai. Untuk uji hipotesis pada penelitian ini menggunaka uji regresi linear sederhana untuk mengetahui ada atau tidaknya pengaruh yang signifikan antara minat belajar dengan kemampuan komunikasi matematis siswa. Hipotesis yang digunakan pada penelitian ini yaitu:

$H_{0}$ : Tidak terdapat pengaruh minat belajar terhadap kemampuan komunikasi matematis siswa SMP kelas VII saat pandemi COVID 19

$H_{1}$ : Terdapat pengaruh minat belajar terhadap kemampuan komunikasi matematis siswa SMP kelas VII saat pandemi COVID 19

\section{HASIL DAN PEMBAHASAN}

Berdasarkan hasil penyebaran angket minat belajar siswa yang dilakukan secara onlinedengan bantuan aplikasi googlefrom. Diperoleh kategori setiap indikator minat belajar matematika yaitu pada indikator perasaan senang berkategori baik, indikator ketertarikan berkategori cukup baik, indikator perhatian dan keterlibatan dalam belajar berkategori cukup baki, indikator rajin belajar dan rajin mengerjakan tugas berkategori cukup baik, indikator tekun dan disiplin dalam belajar berkategori cukup baik, dan indikator memiliki waktu belajar berkategori baik. Sehingga minat belajar siswa berada pada kategori cukup baik. Dengan kata lain, siswa sudah memenuhi indikator minat belajar pada kategori cukup baik. Kemudian pada hasil penyebaran tes uraian kemampuan komunikasi matematis siswa yang dilakukan secara online juga dengan menggunakan bantuan aplikasi whatsapp. Maka diperoleh nilai rata-rata siswa kelas VII sebesar 59,28, sedangkan untuk nilai kriteria ketuntasan minimal (KKM) di sekolah tersebut adalah sebesar 65. Dengan demikian, nilai rata-rata yang diperoleh oleh siswa kelas VII saat mengerjakan tes yang diberikan masih berada dibawah nilai rata-rata yang ditetapkan di sekolah. Pada uraian diatas dapat dilihat bahwa minat belajar matematika siswa kelas VII berada pada kategori yang sangat baik, sedangkan kemampuan komunikasi matematis siswa masih belum mencapai kriteria ketuntasan minimal (KKM) yang ada di sekolah.

Data yang diperoleh sebelumnya akan ubah terlebih dahulu menggunakan methode suksesif interval (MSI) dengan menggunakan bantuan dari Software MS excelyang telah dilengkapi dengan aplikasi Add-In, hal tersebut bertujuan untuk mengubah data ordinal menjadi data interval. Sebelum data tersebut dianalisis, kedua data tersebut haruslah berdistribusi normal. Berdasarkan hasil perhitungan statistik Kolmogorov-Smirnov dengan bantuan Sofware IBM SPSS 25 forwindows diperoleh nilai signifikan sebesar 0,200 20,05, maka $H_{0}$ diterima dengan demikian dapat disimpulkan bahwa data berdistribusi normal. Langkah selanjutnyam data akan dianalisis dengan uji regresi linear sederhana menggunakan bantuan Sofware IBM SPSS 25 forwindows. Tabel 1 menunjukan besarnya pengaruh minat belajar terhadap kemampuan komunikasi matematis siswa SMP kelas VII. 
Tabel 1. Model Summary ${ }^{b}$

\begin{tabular}{lllll}
\hline Model & $R$ & R Square & Adjusted R Square & Std. ErroroftheEstimate \\
\hline $1 \quad 143^{\text {a }}$ &, 020 &,- 010 & 2,30107 \\
\hline a. Predictors: (Constant), minat & & \\
\hline
\end{tabular}

Berdasarkan tabel 1 diperoleh besarnya adjusted $R^{2}$ atau koefisien determinasi adalah 0,020 , hal ini berarti $2 \%$ variansi kemampuan komunikasi matematis dapat dijelaskan oleh variasi dari minat belajar matematika siswa. sedangkan siswanya $100 \%-2 \%=98 \%$ dijelaskan oleh sebab sebab diluar model regresi.Persamaan tersebut hanya dapat menjelaskan pengaruh minat belajar terhadap kemampuan komunikasi matematis sedanayak $2 \%$ saja, sedangkan $98 \%$ lainnya dijelaskan oleh faktor-faktor lain di luar persamaan yang dapat menjelaskan variabel kemampuan komunikasi matematis secara baik.Selain koefisien determinan, adapun bentuk umum persamaan regresi sederhana adalah $\hat{Y}=a+b x$. Dengan menggunakan bantuan Sofware IBM SPSS 25 forwindowsmaka diperolehhasil sebagai berikut:

Tabel 2. Coefficients

\begin{tabular}{|c|c|c|c|c|c|c|}
\hline & \multicolumn{2}{|c|}{ UnstandardizedCoefficients } & \multicolumn{3}{|l|}{ StandardizedCoefficients } \\
\hline & & B & Std. Error & Beta & $\mathrm{t}$ & Sig. \\
\hline \multirow[t]{2}{*}{1} & (Constant) & 12,016 & 3,710 & & 3,239 & ,003 \\
\hline & Minat & 056 & 068 & 143 & 817 & ,420 \\
\hline
\end{tabular}

Berdasarkan tabel 2 diperoleh persamaan regresi linear sederhana yaitu $\hat{Y}=12,016+$ $0,056 x$. Dengan demikian, nilai $\mathrm{a}=12,016$ artinya jika nilai variabel $\mathrm{x}$ adalah 0 maka variabel y adalah 0,056 . Sedangkan nilai $b=0,056$, artinya jika nilai $x$ mengalami perubahan maka nilai y akan mengikuti perubahan dari variabel x tersebut. Selain itu, pada tabel 2 dapat dilihat bahwa nilai signifikasi sebesar 0,420 lebih dari 0,05, maka $H_{0}$ diterima. Berdasarkan hasil uji regresi linear sederhana diperoleh nilai signifikansi koefisien persamaan lebih besar dari nilai taraf signifikan. Dari hasil tersebut dapat disimpulkan bahwa tidak terdapat pengaruh minat belajar matematika terhadap kemampuan komunikasi matematis siswa saat pandemi COVID 19. Hal tersebut sejalan dengan kesimpulan hasil penelitian Widiyato \& Ati(2019) yang mengatakan bahwa minat belajar tidak berpengaruh terhadap keterampilan menulis kalimat argumen. Hasil tersebut menunjukan besarnya pengaruh kedua variabel sangat kecil sehingga sisa dari besar pengaruh tersebut dijelaskan oleh faktor-faktor diluar dari persamaan regresi.

Terdapat beberapa 98\% faktor diluar model regresi yang dapat mempengaruhi kemampuan komunikasi matematis siswa. Faktor afektif selain minat, sepe rti kecemasan belajar (Somawati, 2016), kemandirian belajar (Nurhasanah \& Zhanty, 2019), dan keterampilan sosial (Izzati, 2014) yang berpengaruh terhadap kemampuan komunikasi matematis siswa. Selain ranah afektif, menurut Nufus (2017) menyatakan bahwa terdapat pengaruh interaksi pembelajaran dan level sekolah terhadap peningkatan kemampuan komunikasi matematis siswa.Pemilihan model pembelajaran juga dapat mempengaruhi kemampuan komunikasi matematis siswa, terdapat beberapa model pembelajaran yang dapat dberpengaruh terhadap kemampuan komunikasi matematis siswa seperti model pembelajaran Snowball Throwing (Siregar \& Mardianti ,2020), pembelajaran luar kelas dengan teknik scaffolding (Yunita, 2020), model Think-Talk-Write (TTW) (Sutiawan, Suyono, \& Wiraningsih, 2020), model Lightening The Learning Climate(Andriani, Suhendri, 
\& Liberna, 2019), model pembelajaran Everyday Mathematics dan gaya kognitif (Pambudi, Widada, Nirwana, \& Herawaty, 2020). Selain model pembelajaran secara langsung, konsep pembelajran online atau sering dikenal dengan istilah online learning (ol-learning). Ollearning pada saat ini diperlukan dalam pendidikan, mengingat Indonesia termasuk kedalam negara yang terkena dampak dari COVID-19. Karena proses pembelajaran dilakukan secara online sehingga terdapat beberapa indikator kemampuan komunikasi matematis siswa tidak dapat tercapai sepenuhnya. Pada saat penelitian terdapat beberapa kendala yang ditemukan peneliti diantaranya adalah masalah jaringan, siswa tidak kondusif dan proses berdiskusi dengan teman hasilnya tidak sama saat siswa berdiskusi di kelas. Sejalan dengan kendala yang ditemukan peneliti menurut Tuncay dan Uzunboly (Sukardi \& Rozi, 2019) pembelajaran ol-learning secara murni tidak memungkinkan terjadinya tatap muka didalam kelas sehingga keseluruhan kebutuhan pembelajaran tidak terakomodasi dengan baik, sehingga pembelajaran ol-learning tidak efektif untuk meningkatkan komunikasi siswa. Terdapat faktor lainnya yang dapat mempengaruhi kemampuan komunikasi matematis siswa antara lain pengetahuan prasyarat (prior knowledge), kemampuan membaca, diskusi, dan menulis, serta pemahaman matematik (mathematical knowledge) (Ansari, 2018).

Berikut analisis jawaban tes uraian kemampuan komunikasi matemtis siswa dengan indikator menyatakan benda-benda nyata, situasi dan peristiwa sehari-hari ke dalam bentuk model matematika (gambar, tabel, diagram, grafik, ekspresi aljabar).

1. Dua buah kulit kue samosa yang berbentuk segitiga sama kaki akan disatukan dibagian tepi alasnya sehingga menjadi sebuah bangun datar yang baru. Alas kedua adonan masing-masing $6 \mathrm{~cm}$. Jika tinggi adonan pertama 4,8 $\mathrm{cm}$ dan tinggi adonan kedua 5,6 $\mathrm{cm}$.Gambarkanlah bangun datar yang baru tersebut kemudian carilah luasnya!

Gambar 1 Soal Nomor 1

Adapun jawaban serta solusi yang digunakan oleh siswa untuk menjawab soal nomor 1 . Jawaban yang diberikan oleh siswa diperkuat dengan penjelasan siswa melalui kegiatan wawancara, jawaban dan hasil wawancara ini akan menunjukan tercapai atau tidaknya indikator kemampuan komunikasi matematis pada soal nomor 1 tersebut.

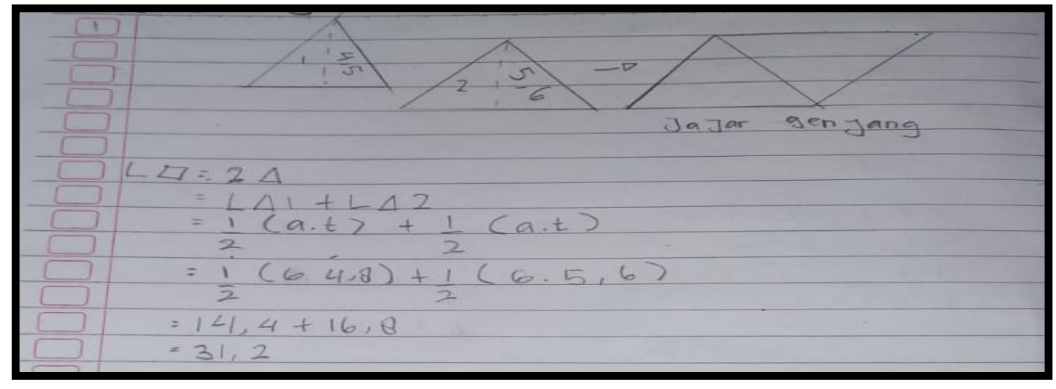

Gambar 2 Jawaban Siswa Pada Soal Nomor 1

Pada gambar 4.3 solusi yang digunakan oleh siswa yaitu dengan menggunakan rumus luas segitiga, meskipun jawabannya benar namun solusi yang digunakan tidak sesuai dengan 
pertanyaan yang terdapat pada soal nomor 1 . Siswa memberikan sebuah gambar bangun datar yang baru setelah kedua segitiga tersebut disatukan dibagian alasnya yaitu sebuah bangun datar jajargenjang, namun gambar yang diberikan salah.

Dengan demikian, untuk soal nomor 1 dengan indikator menyatakan benda-benda nyata, situasi dan peristiwa sehari-hari ke dalam bentuk model matematika (gambar, tabel, diagram, grafik, ekspresi aljabar), masih belum tercapai. Pemahaman matematik menjadi salah satu faktor penyebab belum tercapainya indikator kemampuan komunikasi matematis siswa (Ansari, 2018). Namun hal tersebut bertolak belakang dengan hasil wawancara minat belajar siswa menyatakan bahwa siswa mengerti dengan materi jajargenjang, trapesium, dan layang-layang karena menurutnya pelajaran tersebut seru untuk dipelajari.

\section{SIMPULAN DAN SARAN}

Berdasarkn hasil penelitian mengenai pengaruh minat belajar terhadap kemampuan komunikasi matematis siswa SMP kelas VII dengan sampel penelitian yaitu siswa SMP kelas VII J dengan jumlah siswa sebanyak 36 orang. Hasil analisis data menunjukanpersentase minat belajar matematika siswa berada pada kategori cukup baik dan nilai rata-rata tes kemampuan komunikasi matematis siswa masih berada pada kategori rendah. Dengan demikian, dapat disimpulkan bahwa dengan persamaan regresi $\hat{Y}=12,016+0,056$ dengan koefisien determinasi sebesar $2 \%$. Artinya $2 \%$ variansi kemampuan komunikasi matematis dapat dijelaskan oleh variasi dari minat belajar matematika siswa. Sedangkan siswanya 98\% lainnya dijelaskan oleh sebab-sebab diluar model regresi. Diperoleh nilai signifikansi sebesar 0,420 lebih dari 0,05, maka $H_{0}$ diterima. Artinya tidak terdapat pengaruh minat belajar terhadap kemampuan komunikasi matematis siswa SMP kelas VII saat pandemi COVID 19.

\section{DAFTAR RUJUKAN}

Andriani, D., Suhendri, H., \& Liberna, H. (2019). Pengaruh Model pembelajaran Lightening The Learning Climate Terhadap Kemampuan Komunikasi Matematis Pesertadidik. SIGMA .

Ansari, B. I. (2018). Komunikasi Matematika Strategi Berfikir dan Manajemen Belajar Konsep dan Aplikasi. Banda Aceh: PeNA.

Hendriana, H., \& Sumarmo, U. (2019). Penilaian Pembelajaran Matematika. Bandung: PT Refika Aditama.

Izzati, N. (2014). Pengaruh Keterampilan Sosial Terhadap Kemampuan Komunikasi Matematis Mahasiswa. Jurnal Edueksos .

Maula, Z., \& Kustanti, E. R. (2020). Hubungan Antara Psychological Well-Being dengan Kecenderungan Perilaku Konsumtif Pada Siswa Pengguna Go-Pay Yang Menggunakan Promo Cashback di SMA Negeri 2 Semarang. Jurnal Empati, Volume 8, Nomor 3.

Nurhasanah, R., \& Zhanty, L. S. (2019). Pengaruh Kemandirian Belajar Siswa SMA Terhadap Kemampuan Komunikasi Matematik. Journal On Education .

Pambudi, G. A., Widada, W., Nirwana, \& Herawaty, D. (2020). Penagruh Model Pembelajaran Everyday Mathematics Dan Gaya Kognitif Terhadap Kemampuan Komunikasi Matematika. Jurnal Pendidikan Matematika Raflesia . 
Permendikbud. (2016). Nomor 21 Tahun 2016 Tentang Standar Isi Pendidikan Dasar dan Menengah.

Permendikbud. (2013). Nomor 32 Tahun 2013 Tentang Perubahan Atas Peraturan Pemerintah Nomor 19 Tahun 2005 Tentang Standar Nasional Pendidikan.

Qonaah, A., Pujiastuti, H., \& Fatah, A. (2019, Maret). Pengaruh Model Pembelajaran Generatif terhadap Peningkatan Kemampuan Komunikasi Matematis Ditinjau Dari Kemampuan Awal Matematis Siswa . Jurnal Penelitian Pendidikan dan Pengajaran Matematika .

Rahmayani, S. R., \& Effendi, K. N. (2019). Kemampuan Komunikasi Matematis Siswa SMP Pada Materi Himpunan. Jurnal Pendidikan Unsika, Volume 07 Nomor 01, Maret 2019.

Ritonga, H. (2019). Efektifitas Model Pembelajaran Take and Give Terhadap Kemampuan Komunikasi Matematis Siswa Di SMP Negeri 5 Padangsidimpuan. Mathematical Education Journal, Volume 01 Nomor 02, Juli 2019.

Somawati. (2016). Pengaruh Kecemasan dan Kemandirian Belajar Terhadap Kemampuan Komunikasi Matematis Siswa SMK Negeri di Kecamatan Pasar Rebo. Research and Development Journal of Education .

Sukardi, \& Rozi, F. (2019, Desember). Pengaruh Model Pembelajaran Online Dilengkapi Dengan Tutorial Terhadap Hasil Belajar. Jurnal Ilmiah Penelitian dan Pembelajaran Informatika .

Sutiawan, H., Suyono, \& Wiraningsih, E. D. (2020). Pengaruh Model Pembelajaran Kooperatif Think-Thalk-Write Terhadap Kemampuan Komunikasi Matematis Dan Disposisi Matematis Ditinjau Dari Kemampuan Awal Matematika Siswa. Jurnal Penelitian pembelajaran Matematika .

Yunita, D. (2020). Pengaruh Pembelajaran Luar Kelas dengan Teknik Scaffolding Terhadap Kemampuan Komunikasi Matematis Siswa. Jurnal Pendidikan Matematika Raflesia . 